\title{
RISK FACTORS FOR THYROID CANCER: WHAT DO WE KNOW SO FAR?
}

\author{
Tatjana Bogović Crnčić, Maja Ilić Tomaš, Neva Girotto, Svjetlana Grbac Ivanković
}

Department of Nuclear Medicine, University of Rijeka Faculty of Medicine, Clinical Department of Nuclear Medicine, Rijeka Clinical Hospital Centre, Rijeka, Croatia.

SUMMARY - Thyroid cancer (TC) is the most common endocrine cancer today. The rising incidence of the differentiated papillary type cannot be entirely explained by early and meticulous diagnosis, since a proportion of large tumors has also been reported. In this review, we present the results of numerous investigations focused on possible factors causing increased TC incidence, such as chromosomal and genetic alterations, iodine intake, TSH level, autoimmune thyroid disease, gender, estrogen, obesity, lifestyle changes, and environmental pollutants. Up to now, only childhood exposure to ionizing radiation has been fully recognized as a risk factor. There is also a possibility that yet undiscovered carcinogens, especially during intrauterine life or early childhood, might be responsible for increased TC incidence as well as epigenetic changes. Therefore, more studies are necessary in order to further investigate the potential risk factors for TC and their mechanisms of action.

Key words: radiation exposure, risk factors, thyroid cancer

\section{Introduction}

Thyroid cancer (TC) is the most common endocrine cancer today ${ }^{1,2}$. The two main differentiated forms are the papillary (PTC) and follicular types (FTC). Medullary thyroid cancer (MTC) originates from calcitonin secreting $\mathrm{C}$ cells and is present in $3-5 \%$ of all thyroid cancers. Anaplastic thyroid cancer (ATC) is uncommon but highly aggressive $\mathrm{e}^{1,3}$.

TC incidence has increased all over the world in the last three decades ${ }^{1,4}$. It is believed that improved detection of cancers in the preclinical stage has contributed to this increase ${ }^{4}$, but evidence also suggest a higher true incidence, since an increase in the number of large tumors, especially papillary thyroid cancer, has been reported, without significant change in the follicular and medullary histotypes ${ }^{5}$. The incidence of anaplastic TC has decreased ${ }^{6}$. Mortality from TC, despite earlier diagnosis and better treatment, has not

Corresponding author: Tatjana Bogović Crnčić, Clinical Department of Nuclear Medicine, Rijeka Clinical Hospital Centre, Krešimirova 42, Rijeka, Croatia.

E-mail: tatjanabc@medri.uniri.hr decreased ${ }^{4}$. Therefore, a true increase could indeed be due to early and more sensitive diagnostics but could also be a consequence of population exposure to external factors such as radiation, harmful chemical substances, and carcinogens present in the environment ${ }^{4}$, or it might be multifactorial.

Although the precise causes of TC are still unknown, many studies have searched for possible risk factors; an attempt to review and summarize these factors is presented in this paper (Table 1).

\section{Potential risk factors for thyroid cancer \\ Chromosomal (genetic) alterations}

It seems that the activation of the mitogen-activated protein kinases (MAPK) and phosphoinositide 3 kinase-AKT (PI3K-AKT) signaling pathways might have a role in thyroid cancer growth ${ }^{1}$. In papillary thyroid cancer, activation of the MAPK signaling pathway occurs through two main mechanisms: recombination events and point mutations which are found in almost $70 \%$ of papillary cancers ${ }^{1}$. Chromosomal rearrangements such as rearrangement during transfection of proto-oncogene/papillary thyroid cancer (RET/ 
Table 1. Potential risk factors for thyroid cancer

\begin{tabular}{|c|c|}
\hline 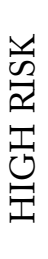 & $\begin{array}{l}\text { Radiation exposure (head and neck region) } \\
\text { Chromosomal (genetic) alterations } \\
\text { Hereditary Conditions } \\
\text { - Hereditary MTC } \\
\text { - Non syndromic FNMTC } \\
\text { - Syndromic FNMTC }\end{array}$ \\
\hline 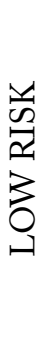 & $\begin{array}{l}\text { Thyroid imaging with iodine } 131 \\
\text { Iodine deficiency } \\
\text { High thyroid stimulating hormone (TSH) level } \\
\text { Autoimmunity } \\
\text { Thyroid nodule/s } \\
\text { Environmental pollutants } \\
\text { Lifestyle and diet } \\
\text { High BMI }\end{array}$ \\
\hline 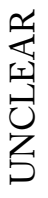 & Estrogen \\
\hline
\end{tabular}

MTC-Medullary thyroid cancer; FNMTC-Familial non-medullary thyroid cancer; BMI-body mass index

PTC), PAX8/PPAR $\gamma$, and B-type Raf kinase/A-kinase anchor protein 9 (BRAF/AKAP9) have been associated with exposure to ionizing radiation and likely represent fragile sites on the chromosome. Point mutations (RAS and BRAF genes) are most likely result of environmentally-induced or stochastic mutagenesis $^{1}$. On the other hand, mutated RAS oncogene and PAX8/PPAR $\gamma$ fusion protein expression caused by translocation both enhance unregulated cell growth in $40 \%$ and $30 \%$ of subjects, respectively ${ }^{7}$, and are expressed in follicular thyroid cancers.

\section{Hereditary conditions}

\section{Familial non-medullary thyroid carcinoma}

TC is probably among the cancers with highest hereditary predisposition ${ }^{1}$, however, more than $90 \%$ is sporadic in nature due to somatic genetic alterations ${ }^{8}$. Approximately $3 \%$ to $9 \%$ of TC is familial non-medullary thyroid carcinoma (FNMTC) with PTC as the most common histologic subtype (85-91\%), followed by FTC (6-10\%), ATC (1.6\%), and Hurthle cell type carcinoma (HTC) $)^{9,10}$. FNMTC is nonsyndromic in $95 \%$ of cases. As opposed to the sporadic type, familial PTC has more aggressive course, with early metasta- ses, higher recurrence rate, and frequent need for radioactive iodine treatment ${ }^{11}$.

\section{Syndromic FNMTC}

Five percent of FNMTC cases can be found in inherited cancer syndromes. Autosomal dominant hereditary syndromes associated with TC are: familial adenomatous polyposis, Cowden syndrome, and Carney complex ${ }^{12}$. Werner syndrome is an autosomal recessive disease with high incidence of neoplasms, such as $\mathrm{TC}^{12}$. Diagnosing a hereditary syndrome is important in order to detect other potentially affected family members and associated diseases ${ }^{12}$.

\section{Medullary thyroid cancer}

MTC is a neuroendocrine tumor present in approximately $3-5 \%$ of incidentally found $\mathrm{TC}$ arising from parafollicular $\mathrm{C}$ cells commonly found in the upper thyroid poles which secrete calcitonin. Sporadic MTC is more frequent than hereditary MTC. Only around $50 \%$ of sporadic MTCs have somatic RET mutations, while nearly all cases of familial MTC (FMTC), multiple endocrine neoplasia 2A (MEN2A), and multiple endocrine neoplasia 2B (MEN2B) have germ line mutations in the RET proto-oncogene. It was discovered that $18-80 \%$ of sporadic MTCs have somatic mutations of $H R A S, K R A S$, or rarely NRAS genes $^{13,14}$.

The familial form of MTC is present in $20-25 \%$ of cases and is usually a component of MEN2A or $2 \mathrm{~B}$, or a part of FMTC syndrome. Mutations of the RET proto-oncogene, situated on chromosome 10q11.2, are responsible for almost all cases of hereditary MTC (FMTC), predominantly located in codons within exons $10,11,13-16^{12}$. Penetrance of MTC is close to $100 \%$ when RET germline mutation is present. ME$\mathrm{N} 2 \mathrm{~A}$ is characterized by bilateral medullary carcinoma or $\mathrm{C}$ cell hyperplasia $(\mathrm{CCH})$, pheochromocytoma, and hyperparathyroidism ${ }^{15}$. In MEN2B, FMTC is associated with marfanoid habitus, mucosal neuromas, ganglioneuromatosis, and pheochromocytoma. In these inherited types of MTC, cancers often develop during childhood with an earlier progression. In hereditary MTC, C cell hyperplasia precedes cancer growth and probably represents clonal proliferation of multiple transformed progenitor cells ${ }^{12}$. 


\section{Estrogen}

The role of estrogen in development of thyroid cancer is still a matter of debate in numerous epidemiological studies. Some studies showed that exogenous estrogen increases the risk, while early loss of ovarian estrogen lowers the risk for thyroid cancer. Many experimental studies performed so far have demonstrated that estradiol behaves as stimulator for either benign or malignant tumors. On the other hand, hormone therapy was associated with very low or no risk for thyroid cancer ${ }^{16}$.

\section{Radiation exposure}

Ionizing radiation interacts with DNA, causing DNA strand breaks in sensitive sites and somatic mutations, consequently inducing carcinogenesis, and is therefore the most-established risk factor for TC. Damaged, but also non-irradiated, adjacent bystander cells show genomic instability. The effect of ionizing radiation is especially harmful in children, since thyroid tissue is very radiosensitive at an early age ${ }^{1}$.

\section{Mechanisms of radiation damage}

Several types of chromosomal rearrangements occur in TC, which are common in other radiation-associated tumors as well. It has been shown that experimentally exposing human thyroid cells to ionizing radiation can induce RET/PTC rearrangement ${ }^{17}$. On the other hand, point mutations involving BRAF and RAS genes which are common in the general population are rare in radiation-related tumors ${ }^{1}$. After the Chernobyl accident, most early cases were solid papillary thyroid cancers with RET PTC-3 rearrangements suggesting radiation damage, while later cases were classic PTC with RET-PTC-1 rearrangements. Other types of RET rearrangements and some BRAF rearrangements were noticed only in a small number of Chernobyl papillary thyroid cancers ${ }^{1}$.

Medical and dental diagnostics have increased thyroid exposure to radiation ${ }^{18}$. Approximately $30 \%$ of all CT scans include the head and neck region, exposing the thyroid ${ }^{19}$ in particular, which is especially radiosensitive $^{1}$. It is known that children exposed to radiation in this part of the body frequently develop PTC, which was also demonstrated by the Chernobyl experience ${ }^{20,21}$. Radiotherapy for head and neck malignancies is also a source of thyroid irradiation. It has also been demonstrated that dental $\mathrm{X}$-rays could represent risk factor for TC in adult age ${ }^{22}$.

\section{Thyroid imaging with iodine 131}

So far, imaging with radioiodine in a diagnostic setting is not correlated with higher incidence of TC, but radioiodine treatment, including larger doses for Graves' disease, might correlate with long-term cancer genesis in a variety of organs, although the risk seems to be quite $\operatorname{low}^{23}$. In a meta-analysis from Hieu et al., it was concluded that the use of radioiodine for hyperthyroidism increased the risk of TC (RR 1.99, 95\% CI: $0.92-1.33$ ), and a dose effect was also observed for the thyroid at doses $>1 \mathrm{~Gy}^{24}$.

\section{Iodine intake}

Iodine deficiency significantly influences thyroid function, since a decrease in the level of thyroid hormones causes a consequent rise in thyroid stimulating hormone (TSH) secretion, which is a major growth stimulating factor for thyroid follicular cells. Therefore, chronic milder iodine deficiency may also be a risk factor for $\mathrm{FTC}^{1}$, although the exact mechanism is still unknown. It is believed that long-term TSH stimulation and BRAF mutations in PTC could be involved in the mechanism ${ }^{25}$. According to the literature, iodine intake might have a role in TC subtype distribution with more follicular cancers in iodine-deficient and predominantly papillary cancers in iodine replete regions ${ }^{26}$. For example, after radioiodine exposure downwind of Chernobyl, it was noted that TC incidence was higher among children from iodine-deficient areas ${ }^{1}$ than in those that were iodine rich $^{27}$.

\section{Thyroid stimulating hormone (TSH)}

It seems that growth factors, primarily IGF-I and insulin, have an important role in thyroid cell growth stimulation mediated by $\mathrm{TSH}^{1}$. The expression of TSH receptors is maintained in well-differentiated thyroid cancers, enabling improved survival of patients treated with suppressive doses of levothyroxine. A fourfold increase of TC incidence as well as higher risk for advanced disease stage was found in patients whose TSH levels were in the upper quartile compared with those in the lower quartile of normal values ${ }^{28}$. There is evidence that TSH renders thyroid cells in mice susceptible to BRAF-induced transformation, probably 
through the cyclic adenosine monophosphate (cAMP) signaling pathway ${ }^{29}$.

\section{Autoimmunity}

There have been only a few studies about the relationship between TC and Graves' disease ${ }^{1}$, but those available suggest an increased risk ${ }^{30}$. The incidence of Hashimoto's thyroiditis (HT) and TC has also increased in the past two decades, suggesting a possible correlation. Several underlying mechanisms have been described. Higher TSH levels in patients with autoimmune thyroid disease stimulate follicular proliferation, thus promoting the development of PTC $^{31}$. Furthermore, histologically proven follicular epithelial dysplasia in the form of scattered microfollicles without colloid and irregularly shaped follicles in HT has been observed. Genesis of TC could also be induced with production of proinflammatory cytokines and oxidative stress in autoimmune thyroiditis ${ }^{32}$. There are also several similarities between HT and PTC in cytological and immunomarker profiles ${ }^{33}$. Surgical series analyzing thyroidectomy results showed a risk for coexistent $\mathrm{PTC}^{34}$. On the other hand, studies using fine needle aspiration cytology specimens showed no significant increase of PTC in patients with $\mathrm{HT}^{35}$. $\mathrm{Pa}-$ tients who have had systemic lupus erythematosus for many years have found to have a higher risk of developing TC, while hydroxychloroquine therapy could be a protective factor ${ }^{36}$.

\section{Thyroid nodules}

It is not certain whether the prevalence of TC is different in thyroid glands with a single nodule compared to multinodular goiter ${ }^{4}$. The general opinion is that patients with multiple thyroid nodules have the same risk of malignancy as those with solitary nodules. There have been studies showing that TC is less frequent in multinodular goiter than in single thyroid nodule, although it appears to be true in the iodinedeficient population only ${ }^{37}$.

\section{Environmental pollutants}

Studies investigating cancer risk factors associated with environmental pollutants have provided interesting results. Some industrialized food additives, such as nitrates from cured meat and some vegetables, can compete with iodine uptake, potentially alter thyroid function ${ }^{38,39}$, and induce thyroid cancer ${ }^{4}$. A study by Ward et al. has shown that above-average nitrate levels in drinking water resources are also associated with an increased risk of thyroid cancer ${ }^{40}$. In recent decades, environmental pollutants which may act as either genotoxic or nongenotoxic carcinogens, such as asbestos, benzene, formaldehyde, pesticides, and many others, have been present ${ }^{4}$. Polybrominated diphenyl ethers (PBDEs) that are used in building materials, electronics, furnishings, motor vehicles, airplanes, plastics, and textiles may induce abnormal thyroid cell proliferation, favoring a precancerous state ${ }^{41}$.

\section{Lifestyle and diet}

Many studies have tried to establish a relationship between dietary habits and TC, but the results are still inconclusive. A population-based case-control study conducted in 2010-2011 showed negative correlation between diet patterns rich in fruits and vegetables and TC risk, especially among women aged 50 or older ${ }^{42}$. A positive correlation was observed between the consumption of cruciferous plants (i.e. brussel sprouts and cabbage) and the risk of TC. It has also been found that above-average consumption of fruits like oranges and lemons was associated with TC risk. Other fruit and vegetables intake in general showed a significantly decreased risk of $\mathrm{TC}^{43}$. Physical activity has been suggested to influence thyroid cancer risk ${ }^{4}$ by improving DNA repair ability, reducing body fat content, lowering resistance to insulin, and altering circulating inflammatory factors ${ }^{44}$. On the other hand, a cohort study by Schmid et al. showed no association between physical activity and TC risk ${ }^{45}$.

The results of a pooled analysis of five prospective studies suggested that cigarette smoking reduces the risk for PTC and probably FTC in $30-40 \%$ of subjects ${ }^{46}$. Smoking can lower the levels of $\mathrm{TSH}^{47}$ and has an anti-estrogenic effect, which can result in a reduced risk of $\mathrm{TC}^{48}$.

A hospital-based case-control study in Korea showed that female patients with positive family history, higher BMI, non-smokers, non-drinkers, and with lower monthly income, had higher risk for TC growth $^{49}$.

\section{Body weight}

The prevalence of PTC was only associated with high BMI (body mass index) in men, while there was 
no statistical difference in women. When multiple risk factors were included in the analysis (younger age, higher serum TSH and lower fasting blood glucose level, smaller nodule diameter, and multifocality), obese individuals had a significantly higher risk for malignancy compared with patients with normal weight. Advanced TNM stage in patients with higher BMI was observed in older men. Most of the obesity was associated with disruptions in insulin metabolism. Insulin-like growth factor1 (IGF-1), which has structural homology to insulin, binds to the IGF-1 receptor and behaves like a potent growth factor that stimulates malignant transformation, tumor progression, and me$\operatorname{tastasis}^{50}$.

\section{Discussion}

Thyroid cancer incidence has significantly increased in recent years. The reason for this growing number worldwide is still unknown and most likely multifactorial. It is thought that the increased incidence is in great part the result of general screening and wide availability of thyroid sonography and aspiration biopsies detecting a higher number of small thyroid tumors ${ }^{1}$. However, according to many authors, the rising TC incidence cannot be explained solely by higher quality screening and detection, so other risk factors have been widely investigated ${ }^{51}$. Among the various studied factors, exposure to ionizing radiation of the head and neck region in childhood is a well-established TC risk factor ${ }^{5,20,21}$, but increased exposure to radiation in general might also contribute ${ }^{4}$. Many studies, summarized and reviewed in this article, have focused on other possible risk factors, such as chromosomal and genetic alterations, iodine intake, TSH level, autoimmune thyroid disease, gender, estrogen, obesity, lifestyle changes, and environmental pollutants $^{52,53,54}$. The results are currently inconclusive, sometimes even controversial, and there is a possibility that yet undiscovered carcinogens, especially during intrauterine life or early childhood, might be responsible for increased TC incidence. Epigenetic changes might also influence thyroid function or induce carcinogenic changes within the thyroid.

Since TC incidence was found to be higher in iodine-deficient areas ${ }^{1,27}$, it is important to encourage studies investigating iodine intake in the population, especially in children and pregnant women, and to promote regular iodine supplementation where appropriate. Additionally, the influence of other already recognized risk factors for cancer development should be further explored in the context of TC manifestation. The impact of geographical, socioeconomic, ethnic, and cultural aspects could also be of interest when TC risk factors are studied.

\section{Conclusion}

It is evident that further studies are necessary in order to investigate the possible risk factors and their pathophysiological mechanisms to be able to control and potentially slow down the continuous increase of thyroid cancer incidence.

\section{References}

1. Bonnefond S, Davies TF. Thyroid Cancer-Risks and Causes. Oncology \& Hematology Review. 2014;10(2):14451. doi: 10.17925/OHR.2014.10.2.144

2. Kusić Z, Prgomet D. Karcinom štitne i doštitne žljezde. In: Prgomet D. Tumori glave i vrata. Zagreb: Medicinska naklada; 2019. p. 262-73. Croatian

3. Hundahl SA, Cady B, Cunningham MP, Mazzaferri E, McKee $\mathrm{RF}$, Rosai J, et al. Initial results from a prospective cohort study of 5583 cases of thyroid carcinoma treated in the United States during 1996. U.S. and German Thyroid Cancer Study Group. An American College of Surgeons Commission on Cancer Patient Care Evaluation study. Cancer. 2000;89(1):202-17. doi: 10.1002 /1097-0142(20000701)89:1<202:aid- cncr27>3.0co;2-a

4. Pellegriti G, Frasca F, Regalbuto C, Squatrito S, Vigneri R. Worldwide increasing incidence of thyroid cancer: update on epidemiology and risk factors. J Cancer Epidemiol. 2013; 2013:965212. doi: 10.1155/2013/965212

5. Liu Y, Su L, Xiao H. Review of Factors Related to the Thyroid Cancer Epidemic. Int J Endocrinol. 2017;2017:5308635. doi: 10.1155/2017/5308635

6. Chen AY, Jemal A, Ward EM. Increasing incidence of differentiated thyroid cancer in the United States, 1988-2005. Cancer, 2009;115:3801-7. doi: 10.1002/cncr.24416.

7. Cheng G, Lewis AE, Meinkoth JL. Ras Stimulates Aberrant Cell Cycle Progression and Apoptosis in Rat Thyroid Cells. Mol Endocrinol. 2003;17(3):450-9. doi: 10.1210/me.20020344

8. Xing M. Molecular pathogenesis and mechanisms of thyroid cancer. Nat Rev Cancer. 2013;(13):184-99. doi: 10.1038/ $\operatorname{nrc} 3431$

9. Peiling YS, Ngeow J. Familial non-medullary thyroid cancer: unraveling the genetic maze. Endocr Relat Cancer. 2016; 23(12):R577-R95. doi:10.1530/ERC-16-0067 
10. Moses W, Weng J, Kebebew E. Prevalence, clinicpathologic features, and somatic genetic mutation profile in familial versus sporadic nonmedullary thyroid cancer. Thyroid. 2011;(21): 367-371. doi:org/10.1089/thy.2010.0256

11. McDonald TJ, Driedger AA, Garcia BM, Van Uum SH, Rachinsky I, Chevendra V, et al. Familial papillary thyroid carcinoma: a retrospective analysis. J Oncol. 2011;2011:948786. doi.org/10.1155/2011/948786

12. Patel KN, Yip L, Lubitz CC, Grubbs EG, Miller BS, Shen W, et al. The American Association of Endocrine Surgeons Guidelines for the Definitive Surgical Management of Thyroid Disease in Adults. Ann Surg. 2020;271(3):e21-e93. doi: 10.1097/ SLA.0000000000003580.

13. Boichard A, Croux L, Al Ghuzlan A, Broutin S, Dupuy C, Leboulleux $\mathrm{S}$, et al. Somatic RAS mutations occur in a large proportion of sporadic RET-negative medullary thyroid carcinomas and extend to a previously unidentified exon.J Clin Endocrinol Metab. 2012; (97):E2031-E2035. doi: 10.1210/ jc.2012-2092.

14. Ciampi R, Mian C, Fugazzola L, Cosci B, Romei C, Barollo S, et al. Evidence of a low prevalence of RAS mutations in a large medullary thyroid cancer series. Thyroid. 2013;(23):50-7. doi. org/10.1089/thy.2012.0207

15. Nosé V. Familial thyroid cancer: a review. Mod Pathol. 2011;24 Suppl 2:S19-33. doi: 10.1038/modpathol.2010.147

16. Luo J, Hendryx M, Manson JE, Liang X, Margolis KL. Hysterectomy, Oophorectomy, and Risk of Thyroid Cancer. J Clin Endocrinol Metab. 2016;101(10):3812-9. doi: 10.1210/ jc.2016-2011

17. Caudill CM, Zhu Z, Ciampi R, Stringer JR, Nikiforov YE. Dose-dependent generation of RET/PTC in human thyroid cells after in vitro exposure to gamma-radiation: a model of carcinogenic chromosomal rearrangement induced by ionizing radiation. J Clin Endocrinol Metab. 2005;90(4):2364-9. doi: 10.1210/jc.2004-1811

18. Mettler FA Jr, Wiest PW, Locken JA, Kelsey CA. CT scanning: patterns of use and dose. J Radiol Prot. 2000;20(4):353-9. doi:10.1088/0952-4746/20/4/301

19. Baker SR, Bhatti WA. The thyroid cancer epidemic: is it the dark side of the CT revolution? Eur J Radiol. 2006;60(1):67-9. doi:10.1016/j.ejrad.2006.04.022

20. Ron E, Lubin JH, Shore RE, Mabuchi K, Modan B, Pottern LM, et al. Thyroid cancer after exposure to external radiation: a pooled analysis of seven studies. 1995. Radiat Res. 2012; 178(2):AV43-60. doi:10.1667/rrav05.1

21. Williams D. Radiation carcinogenesis: lessons from Chernobyl. Oncogene. 2008;27 Supp1 2:S9-18. doi: 10.1038/onc.2009.349.

22. Memon A, Godward S, Williams D, Siddique I, Al-Saleh K. Dental $\mathrm{x}$-rays and the risk of thyroid cancer: a case-control study. Acta Oncol. 2010;49(4):447-53. doi: 10.3109/02841 861003705778.

23. Franklyn JA, Maisonneuve P, Sheppard M, Betteridge J, Boyle P. Cancer incidence and mortality after radioiodine treatment for hyperthyroidism: a population-based cohort study. Lancet. 1999;(353)2111-5. doi:10.1016/S0140-6736(98)12295-X
24. Hieu TT, Russell AW, Cuneo R, Clark J, Kron T, Hall P, et al. Cancer risk after medical exposure to radioactive iodine in benign thyroid diseases: a meta-analysis. Endocr Relat Cancer. 2012;19(5):645-55. doi: 10.1530/ERC-12-0176.

25. Guan H, Ji M, Bao R, Yu H, Wang Y, Hou P, et al. Association of high iodine intake with the T1799A BRAF mutation in papillary thyroid cancer. J Clin Endocrinol Metab. 2009;94 (5):1612-7. doi: 10.1210/jc.2008-2390.

26. Feldt-Rasmussen U. Iodine and cancer. Thyroid. 2001;11(5): 483-6. doi:10.116/s13044-015-0020-8

27. Shakhtarin VV, Tsyb AF, Stepanenko VF, Orlov MY, Kopecky $\mathrm{KJ}$, Davis S. Iodine deficiency, radiation dose, and the risk of thyroid cancer among children and adolescents in the Bryansk region of Russia following the Chernobyl power station accident. Int J Epidemiol. 2003;32(4):584-91. doi:10.1093/jje/dyq205

28. Haymart MR, Repplinger DJ, Leverson GE, Elson DF, Sippel RS, Jaume JC, et al. Higher serum thyroid stimulating hormone level in thyroid nodule patients is associated with greater risks of differentiated thyroid cancer and advanced tumor stage. J Clin Endocrinol Metab. 2008;93(3):809-14. doi:10.1210/ jc. 2007-2215

29. Franco AT, Malaguarnera R, Refetoff S, Liao XH, Lundsmith E, Kimura $\mathrm{S}$, et al. Thyrotrophin receptor signaling dependence of Braf-induced thyroid tumor initiation in mice. Proc Natl Acad Sci U S A. 2011;108(4):1615-20. doi: 10.1073/pnas. 1015557108.

30. Chen YK, Lin CL, Chang YJ, Cheng FT, Peng CL, Sung FC, et al. Cancer risk in patients with Graves' disease: a nationwide cohort study. Thyroid. 2013;23(7):879-84. doi: 10.1089/thy. 2012.0568 .

31. Khatami M. Inflammation, aging, and cancer: tumoricidal versus tumorigenesis of immunity: a common denominator mapping chronic diseases. Cell Biochem Biophys. 2009;55(2): 55-79. doi: 10.1007/s12013-009-9059-2.

32. Vukasović A, Kuna SK, Ostović KT, Prgomet D, Banek T. Diffuse sclerosing variant of thyroid carcinoma presenting as Hashimoto thyroiditis: a case report. Coll Antropol. 2012;36 Suppl 2:S219-21.

33. Ma H, Yan J, Zhang C, Qin S, Qin L, Liu L, et al. Expression of papillary thyroid carcinoma-associated molecular markers and their significance in follicular epithelial dysplasia with papillary thyroid carcinoma-like nuclear alterations in Hashimoto's thyroiditis. Int J Clin Exp Pathol. 2014;7(11):7999-8007.

34. Kurukahvecioglu O, Taneri F, Yüksel O, Aydin A, Tezel E, Onuk E. Total thyroidectomy for the treatment of Hashimoto's thyroiditis coexisting with papillary thyroid carcinoma. Adv Ther. 2007;24(3):510-6. Doi:10.1007/bf02848773

35. Mukasa K, Noh JY, Kunii Y, Matsumoto M, Sato S, Yasuda S, et al. Prevalence of malignant tumors and adenomatous lesions detected by ultrasonographic screening in patients with autoimmune thyroid diseases. Thyroid. 2011;21(1):37-41. doi: 10.1089/thy.2010.0050.

36. Guo JY, Ren ZG, Xuan YY, Li TF, Liu XJ, Niu CZ, et al. Clinical characteristics and risk factors of patients with systemic lupus erythematosus and cancer. Zhonghua Nei Ke Za Zhi. 2020; 59(3):218-221. doi:10.3760/cma.j.issn.0578-1426.2020.03.009 
37. Brito JP, Yarur AJ, Prokop LJ, McIver B, Murad MH, Montori VM. Prevalence of thyroid cancer in multinodular goiter versus single nodule: a systematic review and meta-analysis. Thyroid. 2013;23(4):449-55. doi: 10.1089/thy.2012.0156.

38. Hiasa Y, Kitahori Y, Kitamura M, Nishioka H, Yane K, Fukumoto M, et al. Relationships between serum thyroid stimulating hormone levels and development of thyroid tumors in rats treated with N-bis-(2-hydroxypropyl) nitrosamine. Carcinogenesis. 1991;12(5):873-7. doi:10.1093/carcin/12.5.873

39. Cherrat L, Espina L, Bakkali M, García-Gonzalo D, Pagán R, Laglaoui A. Chemical composition and antioxidant properties of Laurus nobilis L. and Myrtus communis L. essential oils from Morocco and evaluation of their antimicrobial activity acting alone or in combined processes for food preservation. J Sci Food Agric. 2014;94(6):1197-204. doi: 10.1002/jsfa.6397.

40. Ward MH, Kilfoy BA, Weyer PJ, Anderson KE, Folsom AR, Cerhan JR. Nitrate intake and the risk of thyroid cancer and thyroid disease. Epidemiology. 2010,21(3):389-95. doi: 10.1097/EDE.0b013e3181d6201d.

41. Zhang Y, Guo GL, Han X, Zhu C, Kilfoy BA, Zhu Y, et al. Do Polybrominated Diphenyl Ethers (PBDEs) Increase the Risk of Thyroid Cancer? Biosci Hypotheses. 2008;1(4):195-9. doi:10.1016/j.bihy.2008.06.003

42. Liang J, Zhao N, Zhu C, Ni X, Ko J, Huang H, et al. Dietary patterns and thyroid cancer risk: a population-based case-control study. Am J Transl Res. 2020;12(1): 180-190.

43. Choi WJ, Kim J. Dietary factors and the risk of thyroid cancer: a review. Clin Nutr Res. 2014;(3):75-88. doi: 10.7762/cnr. 2014.3.2.75.

44. Samani AA, Yakar S, LeRoith D, Brodt P. The Role of the IGF System in Cancer Growth and Metastasis: Overview and Recent Insights. Endocrine Reviews. 2007;28(1):20-47. doi: 10.1210/er.2006-0001.

45. Schmid D, Behrens G, Jochem C, Keimling M, Leitzmann M. Physical activity, diabetes, and risk of thyroid cancer: a systematic review and meta-analysis. Eur J Epidemiol. 2013;28 (12):945-58. doi: 10.1007/s10654-013-9865-0.
46. Kitahara CM, Linet MS, Beane Freeman LE, Check DP, Church TR, Park Y, et al. Cigarette smoking, alcohol intake, and thyroid cancer risk: a pooled analysis of five prospective studies in the United States. Cancer Causes Control. 2012;23 (10):1615-24. doi: 10.1007/s10552-012-0039-2.

47. Jorde R, Sundsfjord J. Serum TSH levels in smokers and nonsmokers. The 5th Tromso study. Exp Clin Endocrinol Diabetes. 2006;114:343-7. doi:10.1055/s-2006-924264.

48. Derwahl M, Nicula D. Estrogen and its role in thyroid cancer. Endocr Relat Cancer. 2014;21:T273-83. doi: 10.1530/ERC14-0053.

49. Myung SK, Lee CW, Lee J, Kim J, Kim HS. Risk Factors for Thyroid Cancer: A Hospital-Based Case-Control Study in Korean Adults. Cancer Res Treat. 2017;49(1):70-78. doi: 10.4143/ crt.2015.310.

50. Zhao S, Jia X, Fan X, Zhao L, Pang P, Wang Y, et al. Association of obesity with the clinicopathological features of thyroid cancer in a large, operative population. Medicine (Baltimore). 2019;98(50):e18213. doi: 10.1097/MD.0000000000018213.

51. Horvatic Herceg G, Herceg D, Kralik M, Kulic A, Bence-Zigman $\mathrm{Z}$, Tomic-Brzac $\mathrm{H}$, et al. Urokinase plasminogen activator and its inhibitor type- 1 as prognostic factors in differentiated thyroid carcinoma patients. Otolaryngol. Head Neck Surg. 2013;149(4):533-40. doi: 10.1177/0194599813496374.

52. Prstačić R, Bumber B, Marjanović Kavangh M, Jurlina M, Ivković I, Prgomet D. Metastasis predictors for neck sublevel IIb in papillary thyroid. Clin Otolaryngol. 2020;10.1111/ coa.13562. doi:10.1111/coa.13562.

53. Bumber B, Marjanovic Kavanagh M, Jakovcevic A, Sincic N, Prstacic R, Prgomet D. Role of matrix metalloproteinases and their inhibitors in the development of cervical metastases in papillary thyroid cancer. Clin Otolaryngol. 2020;45(1):55-62. doi: 10.1111/coa.13466.

54. Punda A, Bedeković V, Barić A, Kontić M, Čolović Z, Vanjaka Rogošić L, et al. RET expression and its correlation with clinicopathologic data in papillary thyroid carcinoma. Acta Clin Croat. 2018;57(4):646-52. doi: 10.20471/acc.2018.57.04.06.

\section{Sažetak}

\section{RIZIČNI ČIMBENICI ZA KARCINOM ŠTITNE ŽLIJEZDE: ŠTO DANAS ZNAMO?}

\section{T. Bogović Crnčic, M. Ilić Tomaš, N. Girotto i S. Grbac Ivanković}

Etiologija karcinoma štitnjače, kao najčešćeg endokrinog karcinoma intenzivno se istražuje, budući da je njegova incidencija zadnjih desetljeća u stalnom porastu, prvenstveno na račun diferenciranog papilarnog karcinoma. Jedan od glavnih razloga porasta incidencije je zasigurno dostupna i kvalitetna dijagnostika karcinoma u ranoj fazi, međutim, uočava se i porast broja većih tumora, što upućuje na zaključak da vjerojatno postoje i drugi uzroci. U ovom radu izloženi su rezultati brojnih istraživanja usmjerenih na ispitivanje potencijalnih čimbenika rizika koji se dovode u vezu s razvojem karcinoma štitne žlijezde, kao što su kromosomske/genske alteracije, unos joda, razina TSH, autoimuna bolest štitnjače, spol, estrogeni, debljina, životne navike i čimbenici okoliša, od kojih je jedini dokazani čimbenik rizika izlaganje ionizirajućem zračenju u djetinjstvu. Potrebna su daljnja istrǎ̌ivanja s ciljem ispitivanja mogućih čimbenika rizika i njihovih mehanizama djelovanja kako bi se moglo učinkovitije kontrolirati i usporiti pojavnost karcinoma štitnjače.

Ključne riječi: karcinom štitne žlijezde, rizični čimbenici, ionizirajuce zračenje 